\title{
Natural Processes for the Restoration of Dam Removal
}

\section{Disturbances}

\author{
David Franklin Polster \\ Polster Environmental Services Ltd. Duncan, BC V9L 2G5, Canada
}

\begin{abstract}
The Heber River Diversion Dam (Heber Dam) and $3.6 \mathrm{~km}$ penstock on Vancouver island, British Columbia, Canada was built in 1953 and by 2009, it had reached the end of its useful life due to the deteriorated wooden structures. A decision was taken to remove the dam, return the flows in the Heber River to pre-dam conditions and restore the footprint of the dam and penstock. Plans were developed for removal of the dam and contaminated materials including the creosote coated wooden penstock and other wooden structures associated with the dam and site restoration. Work on removal and restoration was undertaken over the summer and fall of 2012 and the spring of 2013. Restoration treatments were based on the use of natural processes as a model for recovery. The recovery of dam and penstock removal disturbances was initiated in the late summer and fall of 2012 with the fall dispersal of seeds from mature pioneering species that formed a significant part of the local undisturbed vegetation. This paper describes the treatments that were applied to enhance the natural recovery of the disturbed areas and the results of those treatments. The restoration treatments were designed to address the filters that were present in project areas. These were identified during an initial inspection in 2009 and were centred on compaction of substrates and a lack of micro-sites. In addition to the use of natural processes for the restoration of project disturbances, a local First Nations crew was hired to transplant sword ferns (Polystichum munitum (Kaulf.) C. Presl) from the adjacent forest areas onto project sites to provide a social benefit from the restoration work.
\end{abstract}

Key words: Natural processes, dam removal.

\section{Introduction}

The Heber River Diversion Dam and penstock (Heber Dam) was constructed in 1953 to take a portion of the flow from the west side of Vancouver island and move it to the east side to increase the flow over BC Hydro dams on the Campbell River to generate power. The Heber Dam was a low head, primarily wooden structure, while the penstock was a $1.83 \mathrm{~m}$ diameter wood stave pipe. After almost 60 years of service the creosote treated wooden dam and penstock had reached the end of its useful life. The dam and penstock either needed to be removed or replaced. An evaluation of the cost-benefit of both options now included the ecological benefits of returning the Heber River, an important west coast salmonid river, to its pre-dammed state. On the cost side, replacement would be in current dollars while

Corresponding author: David Polster, restoration ecologist, research field: restoration ecology. the benefits of additional power generation would face the fact that alternative power generation (wind and solar) is being developed. A decision was taken to remove the dam and penstock, remediate contaminated areas and restore the disturbed areas towards a pre-disturbance condition.

This paper provides details of the restoration treatments that were undertaken at the dam and the recovery results of those treatments. The treatments and recovery results can serve as a template for the restoration of other significantly disturbed sites. At a time when restoration costs might preclude some desired treatments such as landform regrading, topsoil replacement, planting and tending, the demonstration of the effectiveness of natural processes [1] provides a cost-effective alternative to traditional restoration treatments. The first step in defining an effective restoration program is to identify an appropriate local indigenous model (reference ecosystem) that incorporates the role of environmental change in 
shaping the ecosystem that develops [2]. This key concept of ecological restoration fits well with the successional approach defined by Polster, D. F. [3]. The key to identifying the utility of natural processes is to determine the filters [4] that are preventing recovery. At industrial sites compaction with an associated lack of micro-sites and erosion are the most common abiotic filters. Care must be taken to identify and rectify all of the filters [5]. Biotic filters such as lack of propagules can be a problem where new disturbances occur in areas that have not been recently disturbed. The Heber Dam site was disturbed when the dam and penstock were built, so this was not an issue at the Heber Dam. Herbivory can be an issue where traditional reclamation treatments have resulted in a local abundance of seeded grass and legume meadows. These un-natural meadows result in an over-abundance of ungulates that can then cause problems for bird life [6] as well as recovery problems. Understanding the filters that are preventing recovery is the first step in defining an effective restoration strategy.

\section{Methods}

\subsection{Treatment Methods}

In 2009, prior to any work on removing the dam, an assessment of the area was conducted to determine the natural successional processes that operated in the region and to identify filters that might constrain the recovery of the disturbed areas. Plans for restoration of the disturbances associated with removal of the dam and penstock were established. In 2012, the disturbed area was treated using the rough and loose technique described by Polster, D. F. [7]. This creates an array of mounds and holes on the disturbed ground that prevents the overland flow of rainwater which promotes infiltration and thus prevents erosion. The rough and loose ground also creates a diversity of micro-sites that promote a diversity of species establishment [8]. In addition to creating rough and loose ground, the disturbed areas were covered with large woody debris following the methods described by Vinge, T. and Pyper, M. [9] at a rate of $100 \mathrm{~m}^{3} / \mathrm{ha}$.

Commitments had been made to the Mowachaht/Muchalaht First Nation that they would be involved in the restoration work and a crew was hired to transplant sword ferns from the adjacent forest onto the disturbed areas. Incorporation of the social aspects of ecological restoration is important [10]. In addition to bringing the plants onto the restoration areas, transplanting the sword ferns also brought in the soil micro-organisms that are important to the development of a fully functional forest [11]. About 1,000 ferns were moved onto project sites, bringing with them a host of soil micro-organisms.

\subsection{Assessment Methods}

Monitoring of the recovery processes has been undertaken in mid-July each year since completion of dam removal (2013-2017). Monitoring methods were based on the phytosociology methods of Braun-Blanquet, J. [12]. Five transects were established in various parts of the project area. Ten plots were established at $20 \mathrm{~m}$ intervals on each transect. Table 1 provides the locations of the start and end of each transect. Vegetation data collected at each plot followed the techniques outlined in "Describing Terrestrial Ecosystems" [13]. Plots were circular with a radius of $5.65 \mathrm{~m}$ giving a plot area of about $100 \mathrm{~m}^{2}$. For each plot, a listing of the species present along with their cover and abundance was made. Cover and abundance followed a modified Braun-Blanquet scale [14]. This is presented in Table 2. Basic statistical methods were used to analyze the vegetation data.

Table 1 Transect locations.

\begin{tabular}{lll}
\hline Transect & Start location & End location \\
\hline T1 & $10 \mathrm{U} 2904425524982$ & $10 \mathrm{U} 2876845526631$ \\
$\mathrm{~T} 2$ & $10 \mathrm{U} 2878095526706$ & $10 \mathrm{U} 2878255526653$ \\
$\mathrm{~T} 3$ & $10 \mathrm{U} 2890445525094$ & $10 \mathrm{U} 2892105525059$ \\
$\mathrm{~T} 4$ & $10 \mathrm{U} 2886505525318$ & $10 \mathrm{U} 2887845525203$ \\
$\mathrm{~T} 5$ & $10 \mathrm{U} 2876465526721$ & $10 \mathrm{U} 2876845526631$ \\
\hline
\end{tabular}


Table 2 Modified braun-blanquet scale for assigning cover.

\begin{tabular}{lll}
\hline Scale & Numerical value & Meaning \\
$\mathrm{R}$ & 0.1 & One or a few individuals, less than $1 \%$ cover \\
+ & 0.5 & More than a few individuals, but still less than $1 \%$ cover \\
1 & 1 & One or more \\
5 & 5 & $2.5 \%-7.5 \%$ cover, either in one, a few individuals or many \\
10 & 10 & $7.5 \%-12.5 \%$ cover \\
- & - & - \\
95 & 95 & $92.5 \%-97.5 \%$ cover \\
\hline
\end{tabular}

\section{Results and Discussion}

Natural recovery processes have effectively restored the Heber Dam and penstock disturbances. The cost of the restoration work has been significantly less than the cost of traditional reclamation treatments and the diversity of established species has been far greater than with traditional treatments. Simple treatments using readily available methods and materials make the rough and loose treatments very effective for large disturbed sites.

Recovery of the disturbed areas associated with the Heber Dam and penstock removal is proceeding very well. Table 3 presents the salient vegetation characteristics as monitored over the five growing seasons since dam removal. The number of established alder trees has exceeded the agreed upon stocking rate $(4,500$ stems/ha) in every year of monitoring. Similarly, there are conifers and fruit-bearing plants in $98 \%$ of the 50 sampling plots. Species numbers have generally increased over the years and the percent cover of the vegetation has increased every year.

Using natural processes for the restoration of the Heber Dam and penstock removal will ensure that productive ecosystems are established on the disturbed sites. The fact that alders moved onto the disturbed sites early in the process creates conditions of a deciduous cover over the growing conifers which will ensure the conifers grow well [15]. Alders fix nitrogen [16] and provide a rich substrate for the conifers to grow in. In addition, over the first 25 or 30 years of the stand the alder will be above the conifers shade them during the hot summer. In the winter, the alder lose their leaves and the conifers can make use of the sunlight to photosynthesize. The alder will be photosynthesizing in the summer so will be transpiring moisture [17] which will create a cool, moist micro-environment for the conifers. Evaporation of the moisture from the alder stomata require the latent heat of vaporization that will be derived from the air under the canopy therefore cooling the air the conifers are growing in. Unlike conifers grown in the open, the canopy of alder allows the conifers to maintain active photosynthesis through the filtered light of the alder canopy. Since the conifers are not subjected to the temperature extremes of trees growing in the open, they can photosynthesize over a longer period through the day. Thus the conifers grow better in the shade of the alder than those that do not have the canopy of alder.

Natural processes rebuild diverse ecosystems. Creation of a diversity of microsites with the rough and loose technique creates habitat for a diversity of species. There are dry areas at the tops of mounds while moist areas occur in the depressions. This allows a diversity of species to establish. Table 3 presents the total number of species that have been found on the five transects. Species such as Red Columbine (Aquilegia formosa Fisch. ex DC.) and Coast Penstemon (Penstemon serrulatus Menzies ex $\mathrm{Sm}$.) occur in the early successional forests that are currently present at the Heber sites, but these species will not be found in the mature forest that develops. Giesbrecht, I. J. W., et al. [18] have shown that the open nature of floodplain forests maintains a high level of diversity. 
Table 3 Vegetation characteristics.

\begin{tabular}{lllllll}
\hline Year & $\begin{array}{l}\text { No. of } \\
\text { alder/ha }\end{array}$ & Cover of alder No. of species & $\begin{array}{l}\text { No. of conifer } \\
\text { occurrences* }\end{array}$ & $\begin{array}{l}\text { No. of fruit-bearing } \\
\text { plants* }\end{array}$ & Total cover \\
\hline 2013 & 5,412 & $<1 \%$ & 32 & $3(1 \mathrm{spp})$. & $22(5 \mathrm{spp})$. & $1.10 \%$ \\
2014 & 8,550 & $2.60 \%$ & 68 & $31(2 \mathrm{spp})$. & $45(8 \mathrm{spp})$. & $9.20 \%$ \\
2015 & 5,392 & $17.72 \%$ & 80 & $30(4 \mathrm{spp})$. & 47 (9 spp.) & $36.30 \%$ \\
2016 & 6,162 & $27.04 \%$ & 75 & $40(3 \mathrm{spp})$. & $44(11 \mathrm{spp})$. & $46.40 \%$ \\
2017 & 6,963 & $34.58 \%$ & 84 & $49(5 \mathrm{spp})$. & $49(11 \mathrm{spp})$. & $54.00 \%$ \\
\hline
\end{tabular}

*Number of times conifers/fruit-bearing plants occurred in the 50 plots.

Using natural processes to restore the forests of the Heber Dam area is allowing these forests to develop with no pre-conceived ideas about species composition or density. The alder trees that have established on the disturbed sites are currently much denser than those that will be present in a few decades. Similarly, the understory vegetation will shift as the overstory changes. As soils build on the relatively inert gravels of the rough and loose substrate changes in moisture regime will be accompanied by changes in species composition. The natural processes model for ecological restoration [1] provides an opportunity for forests to establish without the constraints of seeded grasses and legumes, planted trees and shrubs or other vestments of traditional reclamation.

\section{Conclusions}

The application of natural processes for the restoration of disturbances associated with the removal of the Heber Dam and penstock has provided a very effective model for recovery of the disturbed sites. By creating conditions that foster the establishment of pioneering species, in this case alder, a wide variety of additional species have established including the conifers of the mature forest. Using the rough and loose treatment with scattered woody debris has proven to be a very efficient model for the recovery of the disturbed sites. A wide variety of species has naturally established on the disturbances including species that may have a role in the early seral forests. These species are in this early seral forest but will not be present in later successional forests. By allowing natural systems to make the decisions about the species composition and cover, diverse ecosystems appear to be establishing on the disturbed sites with every indication that this process will continue. The rough and loose method with woody debris treatments provides a model for other industrially disturbed sites. Identification and amelioration of the filters that prevent recovery and provision of materials (e.g. woody debris) that are found in recovering forest ecosystem (e.g. forest blow-down situations or fires) creates a model that can be used on large industrial disturbances to create natural ecosystems that will be resilient to future conditions.

\section{References}

[1] Polster, D. F. 2009. "Natural Processes: The Application of Natural Systems for the Reclamation of Drastically Disturbed Sites." In Proceedings of the B.C. Technical and Research Committee on Reclamation, BC Mine Reclamation Symposium, 14-7.

[2] McDonald, T., Gann, G. D., Jonson, J., and Dixon, K. W. 2016. International Standards for the Practice of Ecological Restoration-Including Principles and Key Concepts. Washington, DC: Society for Ecological Restoration.

[3] Polster, D. F. 1989. "Successional Reclamation in Western Canada: New Light on an Old Subject." In Proceedings of the Canadian Land Reclamation Association and American Society for Surface Mining and Reclamation Conference, 27-31.

[4] Temperton, V. M., Richard J. H., Tim N., and Stefan, H. eds. 2004. Assembly Rules and Restoration Ecology. Washington, DC: Island Press, 439.

[5] Polster, D. F. 2015. "Effective Strategies for the Reclamation of Large Mines." In Proceedings of the Mine Closure 2015 Conference.

[6] Martin, T. G., Arcese, P., and Scheerder, N. 2011. "Browsing down Our Natural Heritage: Deer Impacts on Vegetation Structure and Songbird Populations across an 
Island Archipelago." Biological Conservation 144: 459-69.

[7] Polster, D. F. 2007. "Mine Reclamation Strategies in British Columbia." In Proceedings of the 32nd Annual Meeting of the Canadian Land Reclamation Association. 25-31.

[8] Larkin, D. J., Sharook, P. M., Janelle, M. W., and Joy, B. Z. 2008. "Topographic Heterogeneity Influences Fish Use of an Experimentally Restored Tidal Marsh." Ecological Applications 18: 483-96.

[9] Vinge, T., and Pyper, M. 2012. Managing Woody Materials on Industrial Sites: Meeting Economic, Ecological and Forest Health Goals through a Collaborative Approach. Edmonton, Alberta: Department of Renewable Resources, University of Alberta, 32.

[10] Clewell, A. F., and Aronson, J. 2013. Ecological Restoration Principles, Values and Structure of an Emerging Profession. Washington, DC: Island Press, 303.

[11] Outerbridge, R. A., and Trofymow, J. A. 2009. "Forest Management and Maintenance of Ectomycorrhizae: A Case Study of Green Tree Retention in South-coastal British Columbia. BC." Journal of Ecosystems and Management 10 (2): 59-80.

[12] Braun-Blanquet, J. 1932. Plant Sociology: The Study of
Plant Communities. Translated by Fuller, G. D., and Conrad, H. S. New York and London: Mc Graw-Hill, 438.

[13] British Columbia Ministry of Forests and Range. 2010. Field Manual for Describing Terrestrial Ecosystems. Victoria, BC: Research Branch, Ministry of Forests and Range.

[14] Mueller-Dombois, D., and Ellenberg, H. 1974. Aims and Methods of Vegetation Ecology. Toronto: John Wiley \& Sons, 547.

[15] Polster, D. F., and Dubois, C. 2007. "Quinsam Coal Mine Reclamation 25 Years of Reclamation Experience." In Proceedings of the 31st annual British Columbia Mine Reclamation Symposium.

[16] Rothe, A., Cromack, J. K., Resh, S. C., Makineci, E., and Son, Y. 2002. "Soil Carbon and Nitrogen Changes under Douglas-fir with and without Red Alder." Soil Sci. Soc. Am. J. 66 (Nov.-Dec.): 1988-95.

[17] Salisbury, F. B., and Ross, C. 1969. Plant Physiology. Belmont: Wadsworth Publishing Company Inc.

[18] Giesbrecht, I. J. W., Saunders, S. C., MacKinnon, A., and Lertzman, K. P. 2017. "Overstory Structure Drives Fine-scale Coupling of Understory Light and Vegetation in Two Temperate Rainforest Floodplains." Can. J. For. Res. 47: 1244-56. 